\title{
FORUM
}

\section{The looting of archaeological heritage}

In 2012, in addition to AP Journal Volume 2, JAS Arqueología also published a book in Spain about the looting of archaeological heritage: Indianas jones sin futuro (Indianas jones without future), by Ignacio Rodríguez Temiño. We then realised there was an urgent need to debate this issue more thoroughly at an international scale, to show how different things can be and try to find better strategies for the protection of archaeological heritage.

While the forum was being designed, a special issue of Internet Archaeology on looting was published (Issue 33) and new projects started to emerge. This shows an increasing interest in these topics and opens the way for wider debates and perspectives.

At first, we thought metal detecting was the main topic to be discussed. Then we started to realise it was just a small part of a wider problem: looting. This is how we decided to initiate a series of forums for the coming years, with a focus on different aspects of looting, and from different perspectives*.

PART I (vol. 3 - 2013) Beyond metal detectors: around the plundering of archaeological heritage.

PART II (vol. 4 - 2014) Conflict and looting: alibi for conflict... and for the looting of archaeological heritage.

PART III (vol. 6 - 2016) Beauty and money: a market that feeds looting.

PART IV (vol. 7 - 2017) Managing development: from the building of a country, to the destruction of archaeological heritage.

*Participation is open for anyone interested, for both published and unpublished parts. We would like the debate to constantly flow among topics. 


\section{PART III}

\section{BEAUTY AND MONEY: A MARKET THAT FEEDS LOOTING}

"I remember the first time I went to Plaza Mayor stamps and coins market in Madrid (Spain). I was a little boy collecting stamps and walked around with my father looming up the tables amazed by the lots of things I saw there. Soon later I started collecting modern coins, until the Euro came and closed the collection with lots of pesetas and a whole series of Euros from each country. That was the moment I started my degree in History and during my last visits to the market I started to spot some roman and medieval coins. Soon I learned about looting and metal detecting..." (Jaime's memories)

Collecting is not a new hobby. For some reason people like to collect, and some museums show now some weird collections (like penises or potties, for example). Collecting art is not new either, and actually some of the masterpieces of modern art exist thanks to it. Popular Culture is aware of that and a new TV show was very interesting to introduce this forum. What would you do if you were "The Last Man on Earth"? Travel around the country and steal some nice artefacts for your own private "collection", like in this The Simpsons Halloween special when Bart and Milhouse stop time with a magic clock.

In the real world, the main problem comes when some collectables are not freely available in the market and also belong to the public domain, at least in some countries. Archaeology is that case and the black market of archaeological artefacts is probably the main trigger for looting. Recent events like the ones in Syria and Iraq with the Islamic State are candent, but Iraq was already the scenario of a coordinated three-day looting back in 2003. Sometimes, museums have been behind the purchase of looted artefacts, but private collectors are still the main market. These are expensive goods and so, power is behind major looting.

\section{*Jaime ALMANSA SÁNCHEZ (update)}

Sometimes things do not go as you expect and this forum is one of them. First in 2015, postponing it as none of the invited authors had replied, now in 2016, with only one contribution and what is going to be my half. 
First I must thank Christos for his piece, which offers a great example of the topic. I cannot really cover for those who did not make it here, but will try to offer a glimpse of what we wanted to have in the following pages.

While studying archaeological heritage management in Madrid, our professor Ma Ángeles Querol, always told us that after people, drugs, and weapons, cultural heritage was the main contraband worldwide. Not in vain, Interpol has a special corps to fight the illegal trade of art and antiquities. Therefore, we wanted this forum to include the perspective of police forces with the collaboration of Interpol on the international market, which moves large amounts of artefacts, not only from conflict areas, and Guardia Civil (Spanish) for a widely spread local market that is the result of low intensity looting in rural areas, specially from metal detectors. Furthermore, we had invited a Spanish researcher that had studied free ports and tax evasion on art and antiquities, but could not meet the deadline due to personal issues. We hope he will be able to write something in the near future, as the topic is very interesting. Some free ports, like Singapore, have special stores for cultural materials that provide all needs for the proper conservation of such goods while providing a safe untaxed space too.

So, when we think about the (illegal) market of cultural heritage, looting is one of the main consequences we face. Is the shortage of this market a solution for the looting of archaeological heritage? How can we redefine values and concerns in a way buyers become more comprehensive? Is police work enough, even if effective? There are many different issues around the topic, and maybe, one of our challenges to face in the near future has to do with addressing them. Public Archaeology has a say on it and we should try to seek for answers. 


\section{Prompt in Theory and Delay in Practice: a case study in museum ethics}

Christos TSIROGIANNIS

Cambridge Archaeological Unit, University of Cambridge

This article investigates the long-delayed repatriation of an Attic red-figure volute krater attributed to the Methyse Painter, returned to Italy from the Minneapolis Institute of Art, that belies the guidelines of the Association of Art Museum Directors (AAMD) for North American museums found to have acquired illicit material. I will introduce the antiquity in question and analyse those involved in its trafficking, acquisition and repatriation, working through the case chronologically to emphasize the differences between theory and practice in museum ethics.

In 1983 the Minneapolis Institute of Art (Mia), ${ }^{1}$ in order to celebrate its centennial (Abbe 2005), acquired an Attic red-figure volute krater, attributed to the Methyse Painter (acc. no. 83.80). ${ }^{2}$ The krater (Fig. 1) depicts Dionysus surrounded by his followers, the satyrs and maenads, as well as a child-satyr depicted on the shoulders of one of the maenads: a scene that is unique in ancient Greek vase painting. The krater was acquired by Mia on the recommendation of Michael Conforti, at that time their head curator (Abbe 2005). Conforti is a former president of the Association of Art Museum Directors and is an advocate of licit markets for antiquities (Gill 2011:58). Using funds from 'The Centennial Fund: Gift of funds from Mr. and Mrs. Donald C. Dayton', ${ }^{3}$ Mia acquired the krater from the antiquities dealers Robin Symes and Christos Michaelides. The krater was published by Michael Padgett (Padgett 1991), then Mia's curatorial assistant.

1 Abbe 2015: 'In early August 2015, the Minneapolis Institute of Arts announced 'that from now on it wants to be known as "Mia" (pronounced Me-ahh). It also has dropped an "s," changing its name to Minneapolis Institute of Art'.

2 The Minneapolis Institute of Art website (http://collections.artsmia.org/ art/3218/athenian-red-figure-volute-krater-attributed-to-the-methyse-painter, last visited 5/9/2016).

3 Ibidem. 


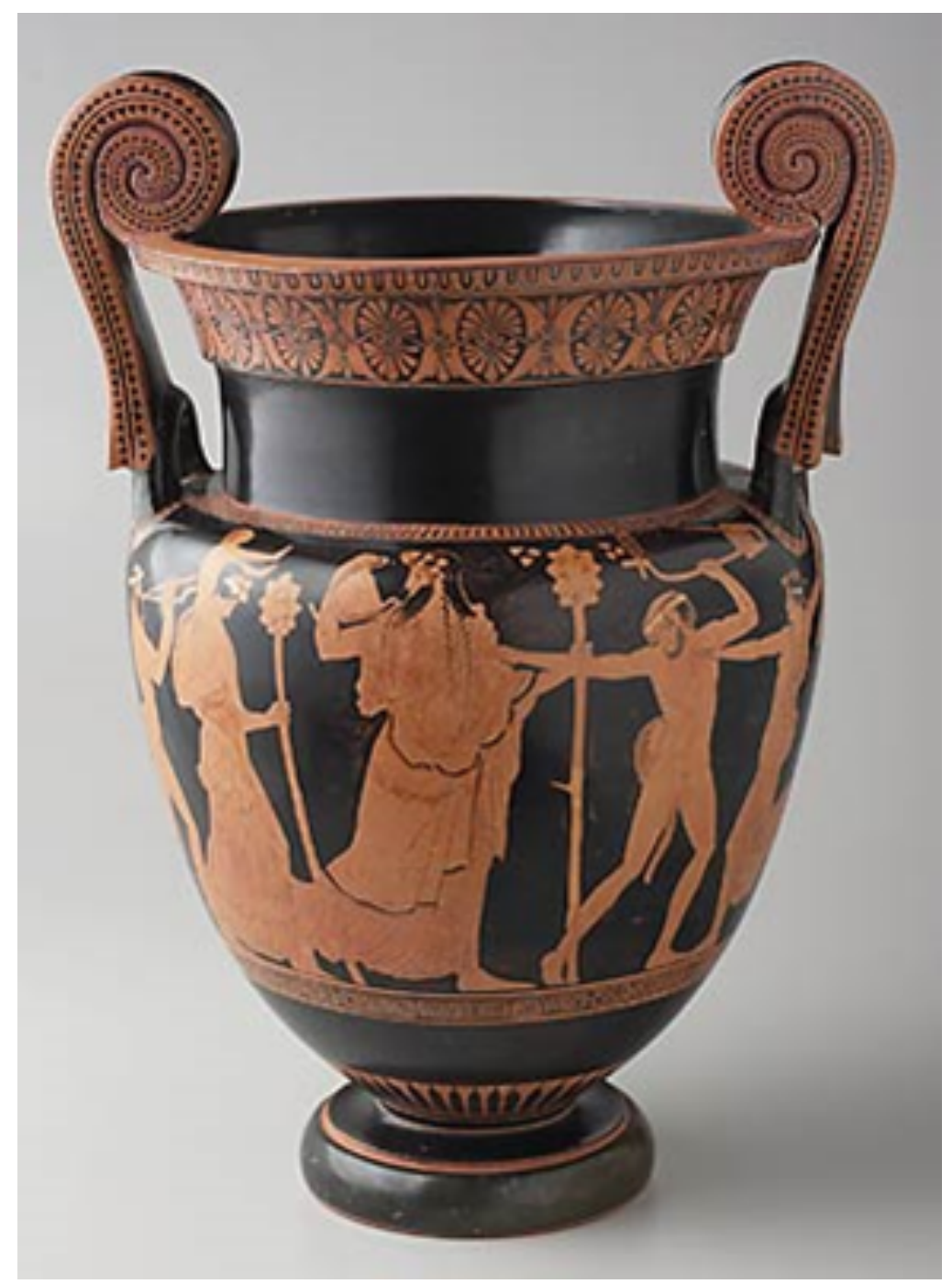

Fig. 1: The Methyse painter krater as depicted on the Minneapolis Institute of Art website (last visited 6/9/2016).

Several of the individuals and institutions mentioned so far are connected at various degrees with the market in illicit antiquities, as I will now show. Above all, Robin Symes and Christos Michaelides dominated the international antiquities market from the mid1970 's until Michaelides' death in 1999, dealing in recently looted antiquities from all over the world (Zirganos 2003:14-16). 
Michael Padgett was working at the Minneapolis Institute of Art (1983-84) at the time the krater was acquired; he then moved to the Boston Museum of Fine Arts (MFA) (1986-90), and since 1992 has been curator of ancient art at the Princeton University Art Museum. ${ }^{4}$ During his assistant curatorship at the Boston MFA, three antiquities were acquired that were later identified as looted and smuggled from Italy (Gill and Chippindale 2006:324$325)$; with ten more, they were eventually repatriated to Italy in 2006 (Watson and Todeschini 2007:298). Padgett published one of the three, a black-figure lekythos depicting Herakles and the Stymphalian birds, in Minerva magazine (Vermeule, Padgett and Herrmann 1990:43); this magazine was at the time owned by Jerome Eisenberg, the owner of 'Royal Athena Galleries' in New York, from where Boston MFA acquired the other two illicit antiquities during Padgett's assistant curatorship. It is worth noting that that gallery was itself required to return illicit antiquities to Italy, some of which were initially stolen from Italian museums (e.g. Godart, De Caro and Gavrili 2008:114-115; 122-123). In 2010 Padgett was accused by the Italian state of 'acquiring nearly two dozen Italian artefacts for the museum that were the property of the Italian government' (Duazo 2010; Gill 2010a) during an investigation of "illegal export and laundering" of Italian archaeological objects (Eakin 2010). After Princeton University Art Museum announced that it would return to Italy illicit archaeological material acquired during Padgett's curatorship between 1993 and 2002 (Gill 2012), the accusations against Padgett were dropped in November 2012 (Bernstein 2013). Since then, however, at least one more antiquity (a lekythos fragment), depicted in the confiscated archive of the illicit antiquities dealer Gianfranco Becchina, has been identified in the Princeton University Art Museum, whose acquisition number (1998-223) shows that it was acquired during Padgett's curatorship (Tsirogiannis and Gill 2014:470).

We now continue the history of the case. In early 2002, two Italian archaeologists, Dr Daniela Rizzo and Maurizio Pellegrini, matched the Methyse Painter Krater in the Minneapolis Institute of Art with an object in three Polaroid images from the confiscated photographic and documentary archive of the illicit antiquities dealer

4 Princeton University Art Museum website (http://artmuseum.princeton.edu/ about/staff-directory/244, last accessed 5/9/2016). 
Giacomo Medici (images no. cd 4, rac. nero oggetti passati cat. A, pag. 14, foto 6-8 and foto 6-8 retro) (personal communication with Rizzo and Pellegrini). The vase appears covered with soil and salt encrustations, in a dark warehouse, on a white table-cloth (Figs. 2-4).
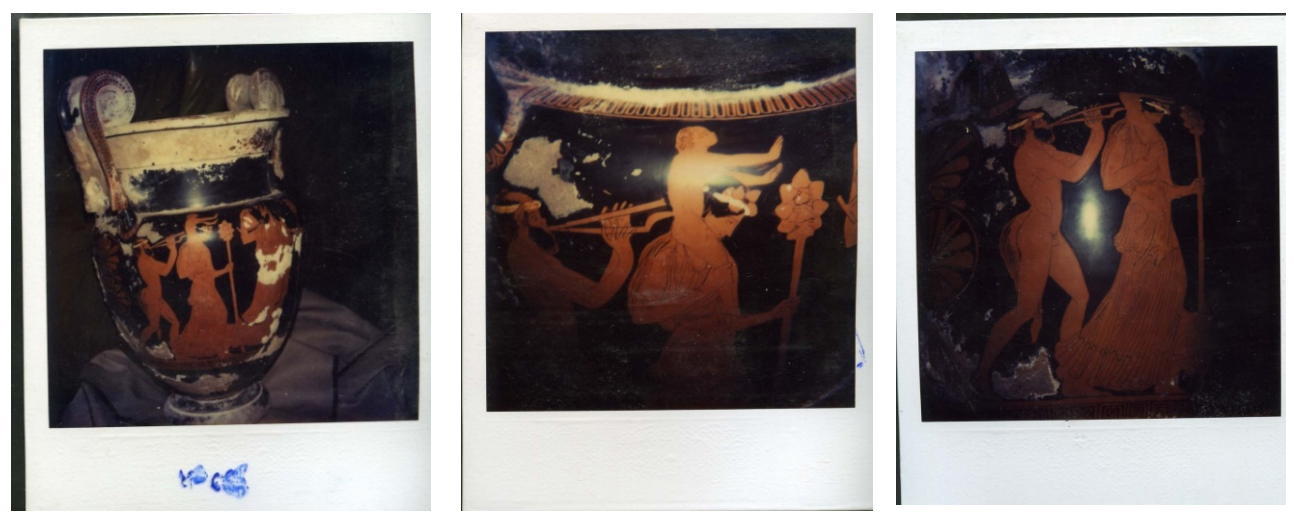

Figs. 2-4: The krater as depicted in three Polaroid images in the confiscated Medici archive.

This archive had been discovered, along with thousands of newly looted antiquities, when Giacomo Medici's warehouses at the Free Port of Geneva was raided by the Swiss and Italian authorities on September 13, 1995; it contains over 4,000 Polaroid, regular-print and professional images, depicting some of the illicit antiquities Medici sold in his career as a dealer. Rizzo and Pellegrini were appointed by public prosecutor Dr Paolo Giorgio Ferri to research the confiscated archive and identify in museums and private collections around the world antiquities of Italian origin depicted in the archive (Watson and Todeschini 2007:53-54; 137). They managed to identify about 300 antiquities, while Giacomo Medici, after appealing twice against a guilty verdict of illegal export of antiquities, receipt of stolen goods and conspiracy (Watson and Todeschini 2007:283), was in December 2011 finally convicted by the High Court in Italy to an eight-year prison sentence and a 10-million-Euro fine (Felch 2012).

In November 2005 Mia issued a press statement (cited by Gill 2007) regarding the krater: 
"The Minneapolis Institute of Arts has learned that an object in our permanent collection could be among a number of objects in American museums that the Italian government alleges to have been recently excavated in Italy. We have not been contacted by the Italian authorities about this object. We have seen only an electronic image of a detail of the shoulder of a vase, which we received from a Los Angeles Times journalist without any accompanying documentation. As a leading museum, we uphold the principle that all collecting be done according to the highest standards of ethical and professional practice. Although no contact or claim has been made, to date, by the Italian authorities, we are nonetheless taking the matter seriously, and, if after gathering the facts it is established that the Italian government has a legitimate claim, we will respond in an appropriate and responsible fashion".

Later that year, the Italian authorities made an official claim for the repatriation of the krater (Abbe 2005). ${ }^{5}$

In April 2006, the Greek authorities raided a summer villa on the island of Schinousa, in the Cyclades where Symes and Michaelides used to spent part of their summer vacation. Among hundreds of unprovenanced antiquities, the police and judicial authorities discovered and confiscated the photographic archive of Symes and Michaelides, in which is depicted only a fraction of the antiquities they sold during their career. Following the Schinousa raid, in which I participated as a forensic archaeologist, I was appointed by the Greek public prosecutor to a mission similar to that of Rizzo and Pellegrini 11 years earlier in Italy: to research the confiscated Symes-Michaelides archive in order to identify antiquities of Greek origin in museums, private collections, auction houses and dealers galleries all over the world. In mid-July 2006, the Italian and Greek authorities exchanged copies of the confiscated archives. In early 2007, I independently identified the Methyse Painter Krater in the Minneapolis Institute of Art depicted in both the Medici and Symes-Michaelides archives (in the latter, free of encrustations, in professional images nos. 1535-1537) (Tsirogiannis 2013a). As can be seen from the images of the krater in Symes-Michaelides

5 Abbe 2005: 'But Italian authorities are claiming it as looted property that rightfully belongs to them'. 
(Figs. 5-7), there is no image in this archive depicting the front side of the vase (shown in the Mia website); however, its identity can be deduced by comparing these images with the three from Medici (Figs. 2-4 above). From experience of other cases involving museum acquisitions from Symes-Michaelides, I find it probable that the Mia owns a Symes-Michaelides image of the front of the vase, since it was standard practice for dealers proposing a sale to send the best image of the object, and if a museum decided to purchase an object, they kept the image.

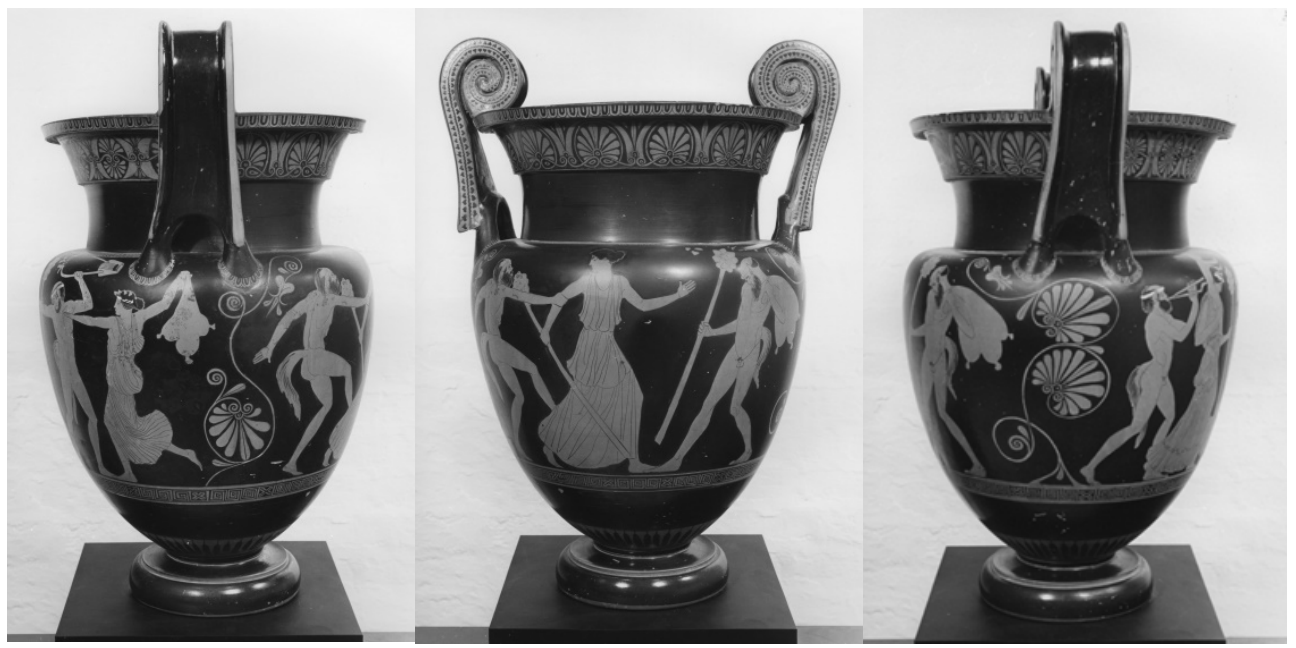

Figs. 5-7: The krater as depicted in three professional images in the confiscated Symes-Michaelides archive.

In another of Padgett's publications (1984:255) the krater's collecting history was given as: '[...] in private collections in Switzerland and Great Britain for ca. 15 years before 1983.' Based on the photographic evidence, it seems that the 'private collections in Switzerland and Great Britain' were in fact the Medici warehouse and the Symes-Michaelides gallery (Gill 2007), while 'ca. 15 years before 1983' (which, as Gill 2010c notes, suggests knowledge of the existence of the object before UNESCO's 1970 Convention on the Means of Prohibiting and Preventing the Illicit Import, Export and Transfer of Ownership of Cultural Property) seems now, under the weight of the evidence, to be false. 
In June 2006, Mia launched an inquiry regarding the krater's acquisition, but by late 2010 the results of this had not been announced (Gill 2010d).

In September 2007, Mia announced the appointment of Kaywin Feldman to the position of director (Mia 2007). In June 2010, Feldman was also appointed President of the Association of Art Museum Directors, previously having been art issues Chairman for AAMD. Feldman succeeded Michael Conforti in the AAMD presidency (Rosenbaum 2010), who, as head curator of Mia, had recommended the acquisition of the krater from Symes and Michaelides. Feldman's experience in these two AAMD positions, in particular, added extra ethical weight to her responsibility as director of Mia to resolve the case of the Methyse Painter Krater without delay.

In June 2008, under Feldman's presidency, the Association of Art Museum Directors issued a New Report on the Acquisition of Archaeological Material and Ancient Art, updating and expanding that created in 2004 (AAMD 2004:4, F). Article 'H' states (AAMD 2008:6, H):

If a member museum, as a result of its continuing research, gains information that establishes another party's right to ownership of a Work, the museum should bring this information to the attention of the party, and if the case warrants, initiate the return of the Work to that party, as has been done in the past. In the event that a third party brings to the attention of a member museum information supporting the party's claim to a Work, the museum should respond promptly and responsibly [emphasis mine] and take whatever steps are necessary to address this claim, including, if warranted, returning the Work, as has been done in the past.

By 2010, five years had passed since the official claim of the krater by the Italian state, and the museum's receipt of the Medici image. Two years after the updated AAMD guidelines, the case of the krater at Mia remained unresolved even though their director was the AAMD president; this suggests that the relevant AAMD guidelines were created to reassure the public that the museums would be acting promptly and responsibly, while actually they are 
procrastinating. Since none of the confiscated Medici or SymesMichaelides images depicting the krater were made publicly available by that time and knowing that such a move would add more pressure to resolve the case on the Minneapolis Institute of Art, on May 19, 2010 I sent all the Medici and Symes-Michaelides images for publication in the Looting Matters blog, maintained by Professor David W. J. Gill. The Medici Polaroid that presents a detail of the krater (fig. 3) was published on May 25, 2010 (Gill 2010b) and the Medici Polaroid that depicts the complete krater largely covered by encrustations (fig. 2) was published on September 1, 2010 (Gill 2010c). Soon after, the Minneapolis Institute of Art decided to return the krater to Italy.

On September 15, 2011, the Minneapolis Institute of Art announced that it would return the krater to the Italian state (Mia 2011):

[...] it was determined that the krater in possession of the MIA is, in fact, the same krater depicted in photographs seized in the course of an investigation conducted by the Comando Carabinieri per la Tutela del Patrimonio Culturale in 1995. The krater likely originated from the archaeological area of Rutigliano, in the Province of Bari, located in the Italian region of Puglia in Southern Italy [...] "The decision to transfer the Volute Krater demonstrates the MIA's commitment to the highest ethical standards in developing and maintaining our collection," said Kaywin Feldman, director and president of the Minneapolis Institute of Art. "Like so many mysteries, this one began with a fragmentary series of clues, calling into question the provenance of work. We are grateful to our colleagues at the Ministry for Cultural Assets and Activities and officials at Homeland Security Investigations for working collaboratively with us to provide information and resolve any ambiguity about this object. " [...] A delivery date to the Italian government is being finalized.

In Rome on May 26, 2015, the Italian authorities were presented 25 repatriated antiquities, among which was the Methyse Painter Krater from Minneapolis Museum of Art (Italian Ministry of Culture and Tourism 2015). On the Minneapolis Institute of Art website the krater is now presented as: 'DEACCESSIONED[:] This artwork was 
deaccessioned (Repatriated) in 2012'.6

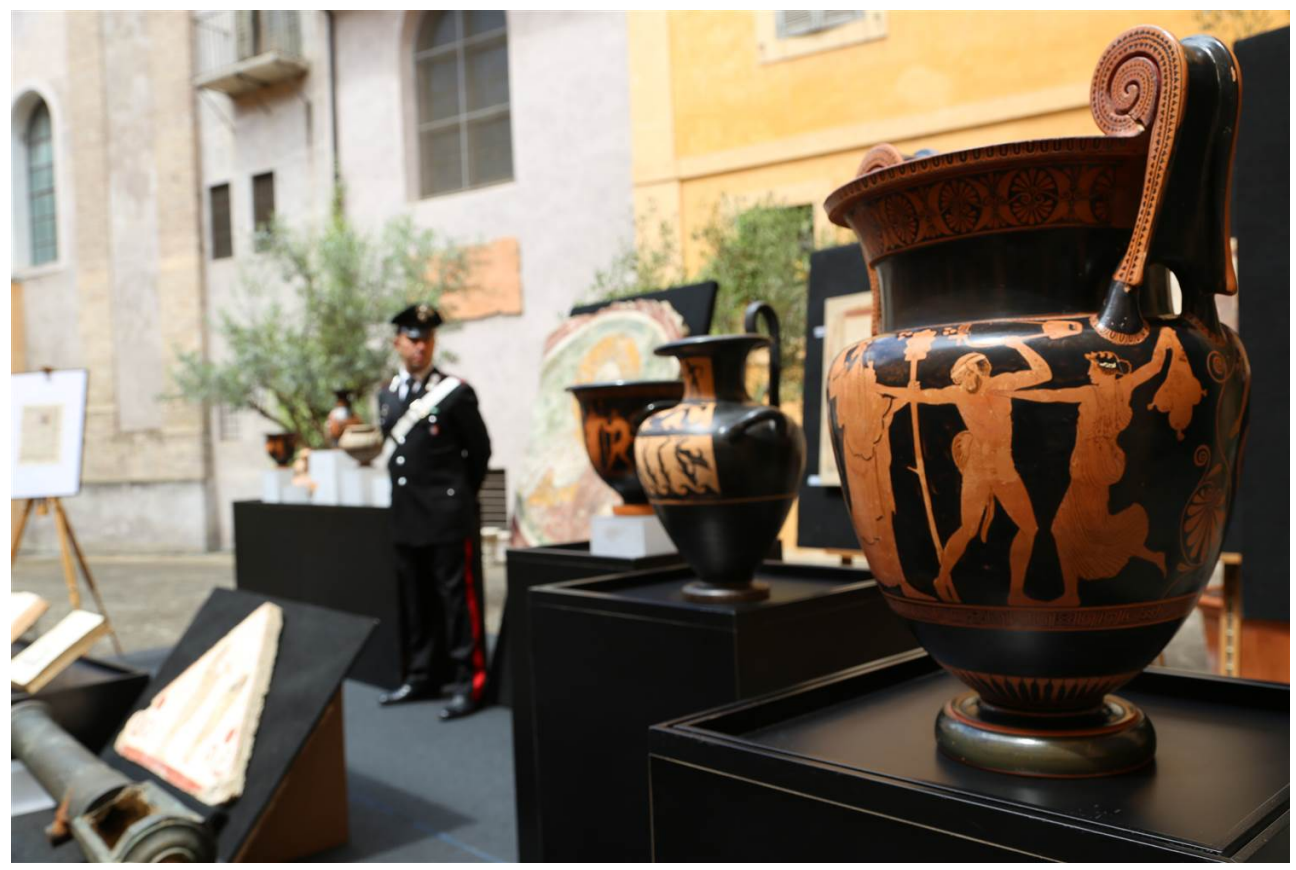

Fig. 8: The krater (right) as presented in Rome after its repatriation from Minneapolis. (C) NBCnews.com

This case of the krater highlights the delay being exercised by institutions involved in the acquisition of illicit antiquities in the post-1970 period (contra the relevant 1970 UNESCO convention, see UNESCO 1970). The reasons for this tactic are to avoid losing the artefact they own and the money paid for its acquisition; but they have to choose between the negative publicity generated because they keep holding onto an illicit antiquity, or the negative publicity that will be generated by the verification of their involvement, mixed with an immediate positive public reaction to news of the institution's decision to return the antiquity/(-ies). It took 6 years for the Minneapolis Institute of Art to admit that the krater was illicit and 10 to

6 http://collections. artsmia.org/art/3218/athenian-red-figure-volute-kraterattributed-to-the-methyse-painter 
return it (after an agreement with the Italian state about the date of repatriation). But such a delay is not an exception; it constitutes the rule among the museum community; despite the AAMD guidelines that are calling for promptness, museums such as the Metropolitan Museum of Art in New York (Tsirogiannis 2014:63-68; Tsirogiannis and Gill 2014:465-467), the Virginia Museum of Fine Arts (Tsirogiannis 2013b:55-60; Tsirogiannis 2013c:81-86), and - again - the Princeton University Art Museum (Tsirogiannis and Gill 2014:470) are still among the museums that for years now have been aware of the illicit material they own, they are aware of the relevant proofs and yet still do not accept their wrongdoing, or even respond when contacted for academic research. The ethical change in the museum world is identical to that in the current antiquities market: it exists as general guidelines but, in practice, has not yet arrived.

\section{Acknowledgements}

I am grateful to Professor David W. J. Gill for his constant support, cooperation and publication of images contributing to the development of the case, to the repatriation of the krater and, especially, keeping the public and the academic community informed on this and other cases. I am also grateful to my colleagues Daniela Rizzo and Maurizio Pellegrini for exchanging information with me on our independent research on the krater's case.

\section{References}

Abbe, Mary. 2005. Italy claims Minneapolis museum holds looted vase, Star Tribune, 9 November.

Abbe, Mary. 2015. Say what? Minneapolis Institute of Art drops an ' $S$ ' and adds a name: 'Mia', Star Tribune, 6 August. Retrieved on 9 September 2016 from WWW [http://www.startribune.com/ minneapolis-museum-suffers-identity-crisis-changes-name-to$\mathrm{mia} / 320959811 /]$

Association of Art Museum Directors (AAMD). 2004. Report of the AAMD Task Force on the Acquisition of Archaeological Materials and Ancient Art, AAMD. 10 June. Retrieved on 
10 September 2016 from WWW [https://aamd.org/sites/ default/files/document/June $\% 2010 \% 20$ Final $\% 20$ Task $\% 20$ Force\%20Report.pdf]

Association of Art Museum Directors (AAMD). 2008. New report on acquisition of archaeological materials and ancient art issued by Association of Art Museum Directors, AAMD. 4 June. Retrieved on 10 September 2016 from WWW [https:// aamd.org/sites/default/files/document/Antiquities $\% 20$ Guidelines\%20with\%20Intro\%2006.08.pdf]

Bernstein, Mark F. 2013. Curator no longer part of probe, Princeton Alumni Weekly.16 January. Retrieved on 9 September 2016 from WWW [https://paw.princeton.edu/article/curator-no-longerpart-probe]

Duazo, Catherine. 2010. Art museum acquisitions face scrutiny over past ownership, Daily Princetonian. 30 November. Retrieved on 9 September 2016 from WWW [http://www.dailyprincetonian. $\mathrm{com} / 2010 / 11 / 30 / 27038 /]$

Eakin, Hugh. 2010. Italy Focuses on a Princeton Curator in an Antiquities Investigation, The New York Times. 2 June. Retrieved on 9 September 2016 from WWW [http://www.nytimes. com/2010/06/03/arts/design/03curator.html]

Felch, Jason. 2012. Italian case against antiquities dealer ends, Los Angeles Times. 19 January. Retrieved on 9 September 2016 from WWW [at http://latimesblogs.latimes.com/ culturemonster/2012/01/italian-antiquities-robert-hecht-caseends.html]

Gill, David W.J. 2007. Minneapolis and Robin Symes, Looting Matters. 1 October. Retrieved on 9 September 2016 from WWW [http://lootingmatters.blogspot.co.uk/2007/10/minneapolisand-robin-symes.html]

Gill, David W.J. 2010a. Princeton: antiquities with a "period of uncertain whereabouts", Looting Matters. 1 December. Retrieved on 9 September 2016 from WWW [http://lootingmatters. blogspot.co.uk/2010/12/princeton-antiquities-with-period-of. html] 
Gill, David W.J. 2010b. Mud on the krater, Looting Matters. 25 May. Retrieved on 10 September 2016 from WWW [http:// lootingmatters.blogspot.co.uk/2010/05/mud-on-krater.html]

Gill, David W.J. 2010c. An Attic Red-figured Krater from the Medici Dossier, Looting Matters. 1 September. Retrieved on 10 September 2016 from WWW [http://lootingmatters.blogspot. co.uk/2010/09/attic-red-figured-krater-from-medici.html]

Gill, David W.J. 2010d. Culture Monster and Minneapolis, Looting Matters. 22 December. Retrieved on 10 September 2016 from WWW [http://lootingmatters.blogspot.co.uk/2010/12/culturemonster-and-minneapolis.html]

Gill, David W.J. 2011. Context Matters: "The Unresolved Case of the Minneapolis Krater", The Journal of Art Crime 5:57-61.

Gill, David W.J. 2012. What has Princeton returned?, Looting Matters. 26 January. Retrieved on 9 September 2016 from WWW [http://lootingmatters.blogspot.co.uk/2012/01/whathas-princeton-returned.html]

Gill, David W.J. \& Christopher Chippindale. 2006. From Boston to Rome: reflections on returning antiquities, International Journal of Cultural Property 13:311-331.

Godart, Louis, Stefano De Caro \& Maria Gavrili (eds). 2008. Nostoi. Repatriated Masterpieces. Athens: Greek Ministry of Culture.

Italian Ministry of Culture and Tourism. 2015. I Carabinieri del Comando TPC Restituiscono al patrimonio culturale 25 straordinarie testimonianze dell' arte italiana consegnate delle autorita statunitensi, Italian Ministry of Culture and Tourism. 26 May. Retrieved on 10 September 2016 from WWW [http://www. beniculturali.it/mibac/export/MiBAC/sito-MiBAC/Contenuti/ MibacUnif/Comunicati/visualizza_asset.html_649573778.html]

Minneapolis Institute of Art. 2007. Kaywin Feldman Appointed New Director, Mia. 25 September. Retrieved on 10 September 2016 from WWW [http://new.artsmia.org/archive/kaywin-feldmanappointed-new-director/] 
Minneapolis Institute of Art. 2011. MIA to Transfer Volute Krater, Mia. 15 September. . Retrieved on 11 September 2016 from WWW [http://new.artsmia.org/press/mia-to-transfer-volutekrater/]

Padgett, Michael J. 1984. Influence of satyric drama on a vase by the Methyse Painter, American Journal of Archaeology 88:255.

Padgett, Michael J. 1991. An Attic red-figure volute krater, The Minneapolis Institute of Arts Bulletin 66:66-77.

Rosenbaum, Lee. 2010. AAMD\&\#146s New President: Who is Kaywin Feldman?, CultureGrrl. 19 May. Retrieved on 10 September 2016 from WWW [http://www.artsjournal.com/culturegrrl/2010/05/ aamds_new_president_who_is_kay.html]

Tsirogiannis, Christos. 2013a. Unravelling the hidden market of illicit antiquities: The Robin Symes-Christos Michaelides network and its international implications. Unpublished Ph.D. thesis. University of Cambridge.

Tsirogiannis, Christos.2013b. From Apulia to Virginia: An Apulian Gnathia Askos at the Virginia Museum of Fine Arts. The Journal of Art Crime 10:81-86.

Tsirogiannis, Christos. 2013c. A Marble Statue of a Boy at the Virginia Museum of Fine Arts. The Journal of Art Crime 9:55-60.

Tsirogiannis, Christos. 2014. A South Italian Bell-Krater by Python in the Metropolitan Museum of Art. The Journal of Art Crime $11: 63-68$.

Tsirogiannis, Christos \& David W.J. Gill. 2014. "A Fracture in Time": A Cup Attributed to the Euaion Painter from the Bothmer Collection. International Journal of Cultural Property 21 (4):465-480.

UNESCO. 1970. Convention on the Means of Prohibiting and Preventing the Illicit Import, Export and Transfer of Ownership of Cultural Property, UNESCO. 14 November. Retrieved on 11 September 2016 from WWW [http://portal.unesco.org/en/ev.phpURL_ID =13039\&URL_DO=DO_TOPIC\&URL_SECTION=201.html] 
Vermeule, Cornelius C., Michael J. Padgett and John J. Herrmann. 1990. New Classical Acquisitions at the Museum of Fine Arts, Boston, Minerva (1) 6:43-45. Retrieved on 9 September 2016 from WWW [http://minervamagazine.co.uk/archive_pdfs/1990_ Vol_1_06.pdf]

Watson, Peter \& Cecilia Todeschini. 2007. The Medici conspiracy. New York (NY): Public Affairs.

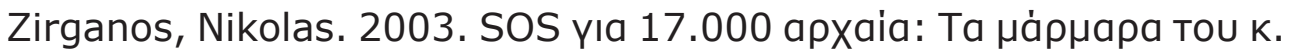

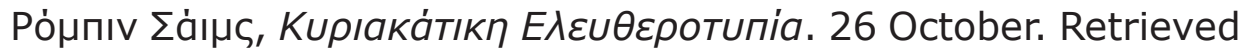
on 6 August 2011 from WWW [http://archive.enet.gr/online/ online_p1_text.jsp?c=110\&id $=81779444,95821940,10292]$ 
